\title{
Family Centered Care versus Child Centered Care: The Malawi Context
}

\author{
Maureen Daisy Majamanda, Tiwonge Ethel Mbeya Munkhondya, Miriam Simbota, \\ Maria Chikalipo \\ Kamuzu College of Nursing, University of Malawi, Blantyre, Malawi \\ Email: mdmajamanda@kcn.unima.mw, tiwongembeya@kcn.unima.mw, msimbota@kcn.unima.mw, \\ mchikalipo@kcn.unima.mw
}

Received 12 January 2015; accepted 22 June 2015; published 26 June 2015

Copyright (C) 2015 by authors and Scientific Research Publishing Inc.

This work is licensed under the Creative Commons Attribution International License (CC BY). http://creativecommons.org/licenses/by/4.0/

(c) (i) Open Access

\begin{abstract}
Family Centered care is a model that is practiced and encouraged in child health care. It considers family as partners and collaborators in care of children. It aims at involving family in all aspects of child care. Family centered care also mentions involvement of child. However, emphasis is given more on family than child and does not take into account the older child's capacity for independent decision making and right to privacy. As such, child's needs are missed out. With child centered care, children are involved and supported at all levels of care based on their age and developmental stage. This paper aims to stress the importance of involving children within family centered care. Involving children in their care, makes them feel less threatened by the health care professional and their self esteem is promoted. Currently, no studies have been identified in Malawi that demonstrates full partnership between the family, child and the nurse. Furthermore, Family Centered Care and Child Centered Care as models are not fully practiced. It is therefore important to practice both family and child centered care in child health care if the needs of both family and children are to be addressed concurrently.
\end{abstract}

\section{Keywords}

Family Centered Care, Child Centered Care, Child Involvement, Child Participation

\section{Introduction}

Family Centered care (FCC) is a model of care that is encouraged in the care of sick children [1] [2]. FCC is defined as

\footnotetext{
"a way of caring for children and their families within health services which ensures that care is planned
} 
around the whole family, not just the individual child, and in which all the family members are recognized as care recipients”. (Shields et al., 2006, p. 1318) [3].

Franck \& Callery (2004), Coyne (1996), Ahmann \& Johnson (2000) and Shields et al. (2007) assert that FCC stresses the importance of considering families and significant others as partners and collaborators in the health care of children and care of family members [1] [4]-[6]. Coyne et al. (2011) described significant others as grandparents and relations to the child. In child headed households, a significant other could be a sibling to the sick child [7].

FCC is built around the following beliefs: empowerment, respecting personal autonomy and recognition of human rights [8]. Empowerment is described by Hawks (1992) as the interpersonal process of providing resources and enabling environment to develop, build and increase the ability and effectiveness of others to set and reach goals [9]. In FCC, family is empowered with knowledge and skills to enable them to participate in the care of the child both in hospital and at home after discharge [10]. Family's ideas and decisions are incorporated in child's care and their rights are respected.

In order to provide FCC and support the family, Mullen \& Pate (2006) suggest development of full partnership between the family of a child and the nurse [11]. They further describe the partnership to include mutual interdependence and equal status between family and nurses. To improve parent outcomes, structured education interventions and necessary emotional support should be applied in FCC [11]. This is also emphasized by Shields and Tanner (2004) who stress that nurses should be sensitive towards the parents' individual needs and recommend that nurses should take a deliberate effort to know and understand the family they are working with [12].

With acute shortage of health care workers in Malawi, Family centered and child centred care are significant during hospitalization. Currently, no studies have been identified that demonstrate full partnership between the family, child and the nurse. In addition, FCC and Child Centered Care as models are not fully practiced.

\section{FCC Practice in Malawi}

Malawi's health system is understaffed and FCC becomes inevitable. Hoffman et al. (2012) reported a health care professional to in patient population ratio of 1:277 [12]. As a result, family members assist with provision of basic patient care like feeding, turning, bathing and administration of oral medication [13]. This has resulted in the shifting of other caring activities from the health care professionals to family members [13]. With extended families, most patients have more than one guardian who helps with care and this prevents exhaustion on guardians as they take turns in managing the patient. However, family members are not well prepared psychologically and are not provided with enough resources to use in the caring role and this brings anxiety to them [13]. Evidence indicates inadequacies in preparation for the caring role among family members [14]-[16]. Some of the contributing factors include: absence of guidelines for orientation of family members on child care, heavy workload by nurses due to increased disease burden and nurses limited knowledge of FCC model and its concepts [13]. Children are rarely or not involved in decision making regarding their care and this result in children's voice not to be heard hence affecting their compliance to treatment. It is important that nurses should be oriented to Family Centred and Child Centred Care models and adapt them to a Malawian setting for their effectiveness.

\section{Benefits of FCC}

Family centered care has benefits for children, family, and health professionals. It has proved to produce improved health outcomes for children through reduced length of hospital stay, readmission rates and emergency visits [17]-[19]. Other benefits of FCC include lower health care costs; more effective allocation of resources; reduced medical errors, decrease in legal claims and legal expenses and results in greater patient, family, and professional satisfaction [13] [20]-[22].

\subsection{Why Child Involvement in FCC?}

FCC also mentions involvement of children in their care [3]. However, this does not come out clearly and it has been observed that emphasis is given more on family than the child [23]. This does not take into account the older child's capacity for independent decision making \& right to privacy and this practice sees child not being actively involved and having other needs unmet. 
To make sure that children's needs are met, it is important to involve and support them at all levels of care and the involvement should depend on their age and developmental stage [24]. Child involvement includes giving children a platform to voice out their concerns, allowing children to do what they can manage to do by themselves and acknowledging children's capacity. It is also important to consult Children on issues affecting their health and involve them in decision making [23]. These can be achieved by communicating directly to the child not through the care giver, informing children about their care and respecting children's views [25]. By doing these things, a child feels less threatened by the health care professional and becomes cooperative [24]. Children's self-esteem is also promoted consequently enhancing their overall welfare [26].

Several times during clinical consultations, health care professionals interact with parents/guardians and information is given to them without involving the child yet the child is there [25]. However, to effectively participate in the care of the sick child, Taylor (2006) points out that a parent requires advocacy, endurance and persistence if the child's voice is to be heard and his or her needs to be met [27]. A child may not be able to communicate directly and effectively to health care workers on his or her needs and requires a parent/care giver to do this on his or her behalf. In the event that a child's wish is against the health care workers' plan of care, a parent has to face the conflict and decide what to do to ensure that both parties are not offended. In her personal experience Taylor (2006) explains that she felt caught in the middle when her 4 years old daughter wanted a Hickman's line removed and a nurse said she needed to have it for a year for monthly treatment and blood tests [27]. If a parent sees that a child's wish or alternative of care makes sense and is not accepted by one clinician, she can refer it to another clinician who may be able to understand the child's and parent's perspective and can grant a child her/his wish.

Another aspect to be considered when managing children is privacy. In a study by Bray (2007), privacy was one of the issues that children indicated that they need during consultations [25]. This was reported in a diary of one child as

It was a bit awkward (to ask questions) cos there was lots of people in the room, it would have been easier if they weren't there $(r 4)$

Similary, Espezel and Canam (2003) recommend an assessment area that is private, relaxed and comfortable to ensure effective information giving and provision of optimum holistic care in children [28]. These findings remind health care professionals to always consider issues of privacy when dealing with children during communication and examination [28]. Children are human beings just like adults therefore need to be treated with respect and dignity.

It is important to make sure that a child's voice should be heard within the FCC framework as children and families may have differing objectives, preferences and perspectives [1] [23]. Similary, Callery et al. 2003 and Jutras et al. 2003 found that views and priorities of children with long-term illness about their health and illness differ from those of their parents [29] [30]. Asking a caregiver alone on the child's complaints or progress is not enough to elicit all the subjective data required. It is therefore important to ask children to describe their feelings and health care professionals need to listen to them with interest and attention.

\subsection{How Should Children Be Involved in FCC?}

Health care professionals should put themselves at the same level with the child if child participation is to be meaningful. This can be achieved by communicating in a language of the child, using simple language that a child can understand and playing with the child where necessary. Aynsley-Green (2001) regards children and young people as competent in defining their needs. He further recommends that their opinions should be included in service evaluation and the planning of care [31]. Just like adults, children also need to be reassured that a health worker is listening to them. This can be demonstrated by utilizing the skills of reflection and non-verbal communication through paraphrasing what they say, looking at them in the eyes, nodding head or holding their hands as they talk [32]. This makes them feel valued and respected. Even in a child who does not talk, asking them in simple terms about their complaints even if they don't respond demonstrates to the child that you care and this can make the child trust you and cooperate in your interactions. In respect for the views of the child, United Nations Convention on the Rights of the Child article 12 states that, when adults are making decisions that affect children, children have the right to say what they think should happen and have their opinions taken into account [33]. However, the Convention recognizes that the level of a child's participation in de- 
cisions must be appropriate to the child's level of maturity.

Giving children chance to express themselves and describe how they are feeling helps them to gain confidence and trust in the health care worker. It has shown that when children are given information that they can understand, they have increased self-esteem and are empowered to take a leading role in issues affecting their health [34]. They demonstrate reduced stress, confusion and misunderstandings and these enhance their well being [26]. Empowered children are able to follow and perform preventive and promotive activities to maintain their health [26]. When sick they are able to comply with treatment and this also lessens the guardians' responsibilities as a child is actively involved.

\subsection{What Happens If Children Are Not Involved?}

When children are not involved in FCC, they become invisible and are missed out completely. Attention is given to family's needs and the child is forgotten in the process.

As such children become dependent on guardians on everything, fail to express themselves and do not develop confidence. Children believe that guardians are better placed to communicate their needs to health care workers and think that their views cannot be taken into consideration hence lack confidence [35].

In terms of treatment, children do not comply with treatment as they do not understand the importance and feel guardians are just forcing them. This makes them feel victimized. It is therefore important to remember that children are key stakeholders in health and healthcare, and not beneficiaries or passive recipients of services [36].

\section{Conclusion}

Children are essential partners in health, involving them in decision affecting their health helps to make sure that their needs are met and their preferences considered. In addition, child participation increases success of care. To make sure that children and family needs are met in child care, it is important to balance Family Centered Care and Child Centered Care in the management of sick children.

\section{Acknowledgements}

All authors for their valued contributions.

\section{References}

[1] Franck, L.S. and Callery, P. (2004) Re-Thinking Family-Centred Care across the Continuum of Children’s Healthcare. Child: Care, Health and Development, 30, 265-277. http://dx.doi.org/10.1111/j.1365-2214.2004.00412.x

[2] Watt, L., Dix, D., Gulati S., Sung L., Klaassen, R.J., Shaw, N.T. and Klassen, A.F. (2011) Family-Centred Care: A Qualitative Study of Chinese and South Asian Immigrant Parents' Experiences of Care in Paediatric Oncology. Child: Care, Health and Development, 39, 185-193. http://dx.doi.org/10.1111/j.1365-2214.2011.01342.x

[3] Shields, L., Pratt, J. and Hunter, J. (2006) Family Centred Care: A Review of Qualitative Studies. Journal of Clinical Nursing, 15, 1317-1323. http://dx.doi.org/10.1111/j.1365-2702.2006.01433.x

[4] Coyne, I. (1996) Parent Participation: A Concept Analysis. Journal of Advanced Nursing, 23, 733-740. http://dx.doi.org/10.1111/j.1365-2648.1996.tb00045.x

[5] Ahmann, E. and Johnson, B.H. (2000) Family-Centered Care: Facing the New Millennium. Pediatric Nursing, 26, 8790.

[6] Shields, L., Pratt, J., Davis, L.M. and Hunter, J. (2007) Family-Centred Care for Children in Hospital. Cochrane Database of Systematic Reviews, 1, Article ID: CD004811. http://dx.doi.org/10.1002/14651858.cd004811.pub2

[7] Coyne, I., O’Neill, C., Murphy, M., Costello, T. and O’Shea, R. (2011) What Does Family-Centred Care Mean to Nurses and How Do They Think It Could Be Enhanced in Practice. Journal of Advanced Nursing, 67, 2561-2573. http://dx.doi.org/10.1111/j.1365-2648.2011.05768.x

[8] Domenighetti, G. (1994) From Ethics of Ignorance to Consumers Empowerment. Social and Preventive Medicine, 39, 123-125. http://dx.doi.org/10.1007/BF01299655

[9] Hawks, J.H. (1992) Empowerment in Nursing Education: Concept Analysis and Application to Philosophy, Learning and Instruction. Journal of Advanced Nursing, 17, 609-618. http://dx.doi.org/10.1111/j.1365-2648.1992.tb02840.x

[10] Fordham, L., Gibson, F. and Bowes, J. (2011) Information and Professional Support: Key Factors in the Provision of 
Family-Centred Early Childhood Intervention Services. Child: Care, Health and Development, 38, 647-653. http://dx.doi.org/10.1111/j.1365-2214.2011.01324.x

[11] Mullen, J. and Pate, M.F.D. (2006) Children and Families in the Intensive Care Unit. In: Slota, M., Ed., Core Curriculum for Pediatric Intensive Care, Elsevier, Philadelphia, 1-30.

[12] Shields, L. and Tanner, A. (2004) Pilot Study of a Tool to Investigate Perceptions of Family-Centered Care in Different Care Settings. Pediatric Nursing, 30, 189-199.

[13] Hoffman, M., Mofolo, I., Salima, C., Hoffman, I., Zadrozny, S., Martinson, F. and Van Der Host, C. (2012) Utilization of Family Members to Provide Hospital Care in Malawi: The Role of Hospital Guardians. Malawi Medical Journal, 24, 74-78.

[14] Hopia, H., Tomlinson, P.S., Paavilainen, E. and Astedt-Kurki, P. (2005) Child in Hospital: Family Experiences and Expectations of How Nurses Can Promote Family Health. Journal of Clinical Nursing, 14, 212-222. http://dx.doi.org/10.1111/j.1365-2702.2004.01041.x

[15] Yui, J.M. and Twinn, S. (2001) Determining the Needs of Chinese Parents during the Hospitalization of Their Child Diagnosed with Cancer: An Exploratory Study. Cancer Nursing, 24, 483-489. http://dx.doi.org/10.1097/00002820-200112000-00011

[16] Abdelkader, R., Alhusami, M., Nassar, M., Mahadeen, A. and Alqadrei, I. (2012) Jordanians Parents’ Needs While Their Child Is Hospitalized. Jordan Medical Journal, 46, 18-27.

[17] Erdeve, O., Arsan, S., Yigit, S., Armangil, D., Atasay, B. and Korkmaz, A. (2008) The Impact of Individual Room on Rehospitalization and Health Service Utilization in Preterms after Discharge. Acta Paediatrica, 97, 1351-1357. http://dx.doi.org/10.1111/j.1651-2227.2008.00889.x

[18] Örtenstrand, A., Westrup, B., Berggren Broström, E., Sarman, I., Åkerström, S., Brune, T., Lindberg, L. and Waldenström, U. (2010) The Stockholm Neonatal Family Centered Care Study: Effects on Length of Stay and Infant Morbidity. Pediatrics, 125, e278-e285. http://dx.doi.org/10.1542/peds.2009-1511

[19] Bhutta, ZA., Kahn, I., Salat, S., Raza, F. and Ara, H. (2004) Reducing Length of Stay in Hospital for Very Low Birth Weight Infants by Involving Mothers in a Step-Down Unit: An Experience from Karachi (Pakistan). BMJ, 329, 1151-1155. http://dx.doi.org/10.1136/bmj.329.7475.1151

[20] American Academy of Pediatrics Committee on Hospital Care (2003) Family-Centered Care and the Pediatrician's Role. Pediatrics, 112, 691-697. http://dx.doi.org/10.1542/peds.112.3.691

[21] Hughes, M. (2007) Parents and Nurses' Attitudes to Family-Centred Care: An Irish Perspective. Journal of Clinical Nursing, 16, 2341-2348. http://dx.doi.org/10.1111/j.1365-2702.2007.01967.x

[22] Abdel Kader, R.H., Arabiat, D.H., Abushaihka, L.A. and Qadri, I. (2013) Mothers' Experience of Caring for Their Hospitalized Child in Jordan's Hospitals. Life Science Journal, 10, 336-342.

[23] Lambert, V. (2011) Commentary on Shields L (2010) Questioning Family-Centred Care. Journal of Clinical Nursing 19, 2629-2638. Journal of Clinical Nursing, 20, 1791-1793. http://dx.doi.org/10.1111/j.1365-2702.2010.03666.x

[24] Moorey, S. (2010) Unplanned Hospital Admission: Supporting Children, Young People and Their Families. Paediatric Nursing, 22, 20-23. http://dx.doi.org/10.7748/paed2010.12.22.10.20.c8133

[25] Bray, L. (2007) Experiences of Young People Admitted for Planned Surgery. Paediatric Nursing, 19, 14-18.

[26] Coyne, I. (2006) Consultation with Children in Hospital: Children, Parents' and Nurses' Perspectives. Journal of Clinical Nursing, 15, 61-71. http://dx.doi.org/10.1111/j.1365-2702.2005.01247.x

[27] Taylor, B. (2006) Giving Children and Parents a Voice-The Parents’ Perspective. Paediatric Nursing, 18, $20-23$.

[28] Espezel, H. and Canam, C. (2003) Parent-Nurse Interactions: Care of Hospitalized Children. Journal of Advanced Nursing, 44, 34-41. http://dx.doi.org/10.1046/j.1365-2648.2003.02765.x

[29] Callery, P., Milnes, L., Verduyn, C. and Couriel, J. (2003) Qualitative Study of Young People and Parents’ Beliefs about Childhood Asthma. British Journal of General Practice, 53, 185-190.

[30] Jutras, S., Morin, P., Proulx, R., Claude Vinay, M., Roy, E. and Routhier, L. (2003) Conceptions of Wellness in Families with a Diabetic Child. Journal of Health Psychology, 8, 573-586. http://dx.doi.org/10.1177/13591053030085008

[31] Aynsley-Green, A. (2001) The NHS Children’s Taskforce and National Service Framework. Paediatric Nursing, 13, 10.

[32] Heimann, K. (2000) Family Needs: How Do We Know What They Want? Paediatric Nursing, 12, 31-35. http://dx.doi.org/10.7748/paed2000.09.12.7.31.c699

[33] The United Nations Convention on the Rights of the Child (accessed 9/01/2015). http://www.unicef.org.uk/Documents/Publicationpdfs/UNCRC_PRESS200910web.pdf

[34] Runeson, I., Mårtenson, E. and Enskär, K. (2007) Children’s Knowledge and Degree of Participation in Decision 
Making When Undergoing a Clinical Diagnostic Procedure. Pediatric Nursing, 33, 505-511.

[35] Coyne, I. and Gallagher, P. (2011) Participation in Communication and Decision-Making: Children and Young People's Experiences in a Hospital Setting. Journal of Clinical Nursing, 20, 2334-2343.

[36] Robertson, S., Pryde, K. and Evans, K. (2014) Quality Improvement: Patient Involvement in Quality Improvement: Is it Time We Let Children, Young People and Families Take the Lead? Archives of Disease in Childhood-Education and Practice Edition, 99, 23-27. http://dx.doi.org/10.1136/archdischild-2013-304327 